\title{
FRAUD DAN WHISTLEBLOWING: TINJAUAN PENGELOLAAN DANA ORGANISASI KEMAHASISWAAN
}

\author{
Salma Mutiara Salsabil \\ Intiyas Utami \\ Aprina Nugrahesthy Sulistya Hapsari \\ Universitas Kristen Satya Wacana \\ esthy@staff.uksw.edu
}

\begin{abstract}
The phenomenon of fraud occurring in the management of educational funds became one of the ideas of the emergence of this study, in particular linked to university funds. The purpose of this research is to describe fraudulent actions that can occur in student organizations. This research is also conducted to see the potential of whistleblowing for fraud prevention and whistleblowing model that can be applied to student organizations. This is a research in the form of descriptive qualitative which exposure of real conditions that occur in the object of research. This research data is in the form of primary data obtained from interviews with members of Student Affairs Faculty of Economics and Business Faculty of " $X$ " University and with field observation. Analytical techniques used through three concurrent activities, namely data reduction, data presentation and conclusion. The results of this study indicate the fraudulent actions that can occur in student organizations related to the misuse of assets and manipulation of reports made by student organizations. There is a potential whistleblowing in student organizations that can serve as a prevention of fraudulent acts and whistleblowing models that can be applied to student organizations is anonymous where the identity of whistleblowers is not disclosed.
\end{abstract}

Keyword : fraudulent, fraud prevention, student organizations, whistleblowing potential, whistleblowing models

\begin{abstract}
ABSTRAK: Fenomena kecurangan yang terjadi dalam pengelolaan dana pendidikan menjadi salah satu ide munculnya penelitian ini, khususnya dikaitkan dengan dana universitas. Penelitian ini dilakukan dengan maksud untuk mendeskripsikan tindakan - tindakan kecurangan yang dapat terjadi dalam organisasi mahasiswa serta melihat potensi whistleblowing sebagai sarana pencegahan kecurangan, serta model whistleblowing yang dapat diterapkan pada organisasi mahasiswa. Penelitian ini merupakan penelitian dalam bentuk deskriptif kualitatif yang berupa pemaparan kondisi nyata yang terjadi di objek penelitian. Data penelitian berupa data primer yang diperoleh dari hasil wawancara dengan anggota Lembaga Kemahasiswaan Fakultas Ekonomika dan Bisnis Universitas X, ditambah dengan hasil observasi lapangan. Teknik analisis yang digunakan melalui tiga alur kegiatan yang dilakukan bersamaan, yaitu reduksi data, penyajian data dan penarikan kesimpulan. Hasil penelitian ini menunjukkan bahwa terdapat tindakan-tindakan kecurangan dalam pengelolaan dana kemahasiswaan yang terjadi di organisasi mahasiswa. Kecurangan ini tergolong dalam penyalahgunaan aset dan manipulasi laporan keuangan yang dibuat oleh organisasi mahasiswa. Selain itu, terdapat potensi terjadinya whistleblowing di organisasi mahasiswa yang dapat dijadikan sebagai sarana pencegahan tindakan kecurangan, karena pada dasarnya kecurangan akan menyebabkan kerugian organisasi. Model whistleblowing yang dapat diterapkan pada organisasi mahasiswa adalah anonymous, model ini merupakan bentuk whistleblowing yang tidak mengungkapkan identitas dari pelapor atau whistleblower.
\end{abstract}

Kata kunci: model whistleblowing, organisasi mahasiswa, potensi whistleblowing, pencegahan kecurangan, tindakan kecurangan 


\section{Pendahuluan}

Kecurangan adalah suatu ancaman yang sering terjadi di dalam suatu organisasi, salah satunya di dalam organisasi kemahasiswaan. Banyak kasus fraud yang terjadi di universitas, sebagai contoh adalah kasus dugaan korupsi proyek pengadaan alat laboratorium di Fakultas Matematika dan Ilmu Pengetahuan Alam (F-MIPA) Universitas Negeri Malang (Puspita et al., 2015).

Salah satu tindakan yang bisa dilakukan di dalam organisasi untuk mencegah tindakan kecurangan adalah dengan dilakukannya aksi whistleblowing. Aksi whistleblowing adalah peristiwa terjadinya pengungkapan kecurangan yang terjadi di dalam organisasi. Aksi whistleblowing tidak wajib untuk dilakukan dan dalam pelaksanaanya pelaku whistleblowing sengaja untuk mengungkapkan kecurangan yang diketahuinya, pelaku whistleblowing atau yang biasa disebut dengan whistleblower memiliki akses atas informasi - informasi yang berkaitan dengan tindakan kecurangan yang terjadi di dalam organisasinya (Yeoh, 2014).

Terdapat banyak kasus kecurangan yang terungkap melalui aksi whistleblowing, salah satu contohnya adalah kasus Susno Duadji yang mengungkapkan informasi informasi penting yang berkaitan dengan kasus penggelapan pajak oleh Gayus Tambunan. Contoh kasus lainnya adalah penggelapan solar bersubsidi yang dilakukan oleh PT. Ganda Sari, salah satu mantan pegawai PT. Ganda Sari mengungkapkan kasus kecurangan yang dilakukan oleh atasan PT. Ganda Sari yang diketahui menimbun 3,7 juta liter solar bersubsidi yang dapat menimbulkan kerugian bagi negara (Mada, 2012). Kasus dugaan korupsi yang terjadi pada FIFA juga diperbantukan oleh seorang whistleblower dalam pengungkapannya. Mantan Komite Eksekutif FIFA, Chuck Blazer membantu Federal Bureau of Investigation (FBI) dalam membongkar kasus korupsi yang terjadi pada FIFA (Christian, 2015).

Aksi whistleblowing dapat dilakukan dengan dua model yaitu model anonymous dan non-anonymous. Model anonymous dilakukan dengan cara tidak mengungkapkan identitas dari pelapor kecurangan atau whistleblower kepada publik. Berlawanan dengan model anonymous, model non-anonymous mengungkapkan identitas pelapor kecurangan ke publik (Gokce, 2013).

Kasus - kasus pengungkapan kecurangan telah banyak terjadi pada organisasi besar, akan tetapi tindakan kecurangan dapat terjadi pada setiap organisasi. Organisasi besar maupun kecil dapat menerima ancaman berupa kecurangan yang dapat merugikan organisasi. Aksi whistleblowing belum begitu familiar pada organisasi - organisasi kecil, contohnya saja organisasi mahasiswa. Organisasi mahasiswa berbeda dengan organisasi - organisasi besar yang sebagian besar memiliki tujuan untuk menghasilkan profit bagi organisasi sehingga rentan terjadi tindak kecurangan. Akan tetapi, salah satu tujuan dari terbentuknya organisasi mahasiswa adalah menciptakan calon calon pemimpin yang kritis - prinsipil, kreatif - realistis dan non - konformis, sehingga ada baiknya anggota organisasi mahasiswa dilatih untuk bertanggung jawab sejak dini (UKSW, 2011).

Tindakan kecurangan yang dapat terjadi pada organisasi mahasiswa bisa mencakup jenis - jenis ancaman yang ada pada fraud tree, maka dari itu penelitian ini akan melakukan penelitian terhadap tindakan kecurangan kecurangan yang dapat terjadi dalam organisasi mahasiswa. Penelitian ini juga akan melihat ada atau tidaknya potensi whistleblowing terhadap tindakan kecurangan yang terjadi pada organisasi mahasiswa untuk pencegahan kecurangan 
dan menentukan model whistleblowing yang dapat diterapkan pada organisasi mahasiswa.

Penelitian ini dilakukan pada Lembaga Kemahasiswaan yang dimiliki oleh Fakultas Ekonomika dan Bisnis Universitas " $X$ " yang belum menerapkan mekanisme whistleblowing dalam kegiatannya. Penelitian ini bertujuan untuk mengidentifikasi jenis tindakan kecurangan yang terjadi di lingkungan lembaga kemahasiswaan, selain itu juga bertujuan untuk melihat adanya potensi serta model whistleblowing yang dapat dipakai sebagai sarana untuk memitigasi kecurangan di lembaga kemahasiswaan. Penelitian ini diharapkan dapat memberikan kontribusi dalam ilmu akuntansi, khususnya terkait audit dan keperilakuan berupa jenis kecurangan yang potensial terjadi dalam lembaga kemahasiswaan, serta menambah literatur terkait model whistleblowing yang dapat diterapkan dalam organisasi kemahasiswaan tersebut.

\section{Kajian Pustaka}

\section{Kecurangan (Fraud)}

Menurut Association of Certified Fraud Examiners (ACFE, 2017) sebagai organisasi terbesar anti fraud di dunia, definisi fraud atau yang biasa disebut dengan kecurangan adalah salah satu tindakan yang melanggar peraturan peraturan yang telah diterapkan dan bertujuan untuk mendapatkan keuntungan pribadi. Kecurangan dapat dilakukan oleh individu atau kelompok dengan melakukan segala cara yang dapat merugikan organisasi. ACFE juga mendefinisikan kecurangan sebagai suatu tindakan yang disengaja dan pelaksanaannya tidak sesuai dengan peraturan - peraturan yang telah diterapkan. Kecurangan dilakukan dengan tujuan untuk mendapatkan keuntungan pribadi atau kelompok.
ACFE (2017a) juga mendefinisikan kecurangan yang terjadi pada suatu organisasi dapat dibagi menjadi tiga jenis yaitu (1) korupsi, (2) penyalahgunaan aset dan (3) kecurangan pada laporan keuangan. Kecurangan dalam bentuk korupsi dilakukan dengan cara menyalahgunakan kekuasaan untuk mengambil sesuatu yang bukan menjadi hak milik dari pelaku korupsi. Penyalahgunaan aset merupakan tindakan kecurangan yang pada umumnya dilakukan oleh anggota organisasi dengan cara memanfaatkan aset organisasi untuk kepentingan pribadi. Tindakan kecurangan juga dapat dilakukan dengan cara memanipulasi laporan keuangan, dalam memanipulasi laporan keuangan pelaku kecurangan dapat mengubah hasil laporan keuangan bahkan memalsukan dokumen yang terkait dengan laporan keuangan (Kummer et al., 2015).

Kecurangan dapat terjadi karena adanya tiga kondisi yaitu tekanan, peluang dan rasionalitas. Tekanan (pressure), peluang (opportunity) dan rasionalitas (rasionalization) merupakan kondisi yang mendasari terjadinya kecurangan pada organisasi, ketiga faktor ini disebut dengan Fraud Triangle. Kecurangan didasari oleh tekanan yang dirasakan oleh pelaku kecurangan, peluang dan kondisi lingkungan yang mendukung pelaku kecurangan untuk melakukan kecurangan dan kecurangan yang dilakukan oleh pelaku kecurangan dianggap rasional sehingga pelaku kecurangan membenarkan tindak kecurangan yang dilakukannya (Tiffani dan Marfuah, 2015).

\section{Whistleblowing}

Tindakan whistleblowing didefinisikan sebagai pelaporan kecurangan yang berkaitan dengan bidang akuntansi yang dilaporkan oleh salah satu anggota organisasi kepada pihak lain yang ada di dalam organisasi maupun di luar organisasi (Setiawati dan Sari, 2016). Dengan dilakukannya whistleblowing 
didalam suatu organisasi dapat meningkatkan keamanan dalam organisasi terhadap ancaman yang berjeniskan tindakan kecurangan. Whistleblowing yang dilakukan oleh anggota organisasi dapat meminimalkan ancaman yang dilakukan oleh anggota yang ada dalam organisasi karena secara tidak langsung anggota yang tergabung di dalam organisasi saling mengawasi satu sama lain (Setiawati dan Sari, 2016).

Pelapor kecurangan dalam organisasi disebut dengan whistleblower, whistleblower sendiri bisa merupakan pihak internal atau eksternal yang berhubungan dengan organisasi. Dalam melaporkan tindakan kecurangan, whistleblower harus memberikan beberapa bukti yang dapat memperkuat laporannya agar bisa diproses. Pelaporan yang dilakukan oleh whistleblower adalah pelaporan terhadap kecurangan yang dilakukan oleh sesama anggota kepada pejabat yang berwenang (Sagara, 2013).

Tindakan whistleblowing yang dilakukan dalam suatu organisasi dapat memberikan manfaat bagi organisasi, diantaranya dapat meminimalkan kecurangan yang terjadi didalam suatu organisasi karena setiap anggota merasa diawasi satu sama lain didalam kinerjanya. Tindakan whistleblowing dapat menimbulkan rasa enggan pada diri anggota untuk melakukan kecurangan karena anggota percaya dengan sistem pelaporan yang menjadi salah satu pengendalian yang efektif. Whistleblowing dapat dilakukan oleh semua anggota didalam organisasi atau organisasi (Agusyani et al., 2016).

Aksi whistleblowing dapat dilakukan dengan dua model yaitu model anonymous dan non-anonymous. Model anonymous dilakukan dengan cara tidak mengungkapkan identitas dari pelapor kecurangan atau whistleblower kepada publik. Pelapor kecurangan dapat menggunakan nama singkatan pada saat melakukan pelaporan kecurangan atau tidak memberikan informasi mengenai indentitasnya sama sekali jika menggunakan model anonymous. Berlawanan dengan model anonymous, model non-anonymous mengungkapkan identitas pelapor kecurangan ke publik untuk diketahui (Gokce, 2013).

\section{Pencegahan Fraud}

Pencegahan fraud merupakan salah satu aktivitas yang dapat meminimalisirkan tindakan kecurangan. Aktivitas pencegahan fraud dapat dilakukan dengan cara menerapkan berbagai kebijakan dan prosedur didalam organisasi. Kebijakan - kebijakan yang dapat diterapkan oleh organisasi merupakan bentuk pengendalian yang dilakukan untuk mengatur atau mengawasi kinerja dari anggota yang terlibat dengan organisasi. Dengan adanya prosedur atau kebijakan yang diterapkan oleh organisasi anggota dapat dengan mudah mengerti apa saja yang harus dikerjakan. Perlakuan anggota yang menyimpang dari prosedur yang sudah ditetapkan dapat teridentifikasi sebagai kecurangan (Arfah, 2011)

Pencegahan terhadap tindakan kecurangan dilakukan dengan tujuan untuk mengurangi risiko yang dapat merugikan organisasi yang disebabkan oleh tindakan yang curang atau disengaja. Pencegahan tindakan kecurangan dapat dilakukan kapanpun untuk mengantisipasi risiko kecurangan yang dapat terjadi, ada baiknya pencegahan ini dilakukan sejak dini. Penerapan pencegahan terhadap tindakan kecurangan sejak dini dapat membantu organisasi dalam mempersempit risiko kerugian dan mengidentifikasi kecurangan yang dapat terjadi dalam organisasi (Gaurina et al., 2017).

\section{Metode Penelitian}

Desain penelitian ini menggunakan metode deskriptif kualitatif, penelitian ini mengumpulkan informasi mengenai kecurangan yang dapat terjadi pada 
lembaga kemahasiswaan serta melihat ada atau tidaknya potensi whistleblowing untuk pencegahan kecurangan dan model whistleblowing yang dapat diterapkan pada organisasi mahasiswa. Penelitian ini dilakukan pada Lembaga Kemahasiswaan yang dimiliki oleh Fakultas Ekonomika dan Bisnis Universitas " $\mathrm{X}$ ".

Data yang digunakan dalam penelitian ini berupa informasi dari mahasiswa yang aktif dalam Lembaga Kemahasiswaan Fakultas Ekonomika dan Bisnis Universitas " $\mathrm{X}$ " mengenai kecurangan, potensi whistleblowing untuk pencegahan kecurangan dan model whistleblowing yang dapat terjadi pada organisasi mahasiswa yang diperoleh dari wawancara secara semi terstruktur kepada mahasiswa yang tergabung pada lembaga kemahasiswaan. Wawancara yang dilakukan memiliki panduan pertanyaan yang kemudian dikembangkan sedemikian rupa untuk dapat memperoleh jawaban atas persoalan penelitian. Hal lain yang dilakukan sebagai teknik pengumpulan data adalah dengan melakukan observasi dalam kegiatan atau rutinitas keseharian dari organisasi mahasiswa. Observasi yang dimaksudkan dalam penelitian ini adalah peneliti terlibat langsung dalam kegiatan kemahasiswaan, sekaligus melakukan pengamatan dalam operasional lembaga kemahasiswaan.

Teknik analisis penelitian kualitatif dilakukan dengan melalui tiga alur kegiatan yang dilakukan bersamaan setelah adanya wawancara dan observasi yang dilakukan, yaitu reduksi data dilakukan dengan memilah data hasil wawancara untuk kemudian disesuaikan dengan persoalan penelitian, dilanjutkan dengan tahapan penyajian data dengan mengerucut pada hasil penelitian dan terakhir adalah tahapan penarikan kesimpulan. Secara garis besar tahapan yang akan disajikan dalam penelitian ini adalah : (1) menyajikan profil dari Lembaga Kemahasiswaan Fakultas Ekonomika dan Bisnis Universitas "X";
(2) mengidentifikasi kecurangan yang dapat terjadi pada lembaga kemahasiswaan dengan pendekatan jenis kecurangan sesuai yang dikemukakan oleh ACFE; (3) mengindentifikasi adakah potensi whistleblowing untuk pencegahan kecurangan; (4) menentukan model whistleblowing yang dapat diterapkan pada organisasi mahasiswa.

\section{Hasil Dan Pembahasan}

\section{Identifikasi Kecurangan dalam Organisasi Mahasiswa}

Dalam pelaksanaan aktivitas pada Lembaga Mahasiswa Fakultas Fakultas Ekonomika dan Bisnis telah ditetapkan prosedur Ketentuan Umum Keluarga Mahasiswa dan Mekanisme Kerja Eksekutif untuk mempermudah kinerja dari anggota organisasi mahasiswa yang tergabung pada LKF Fakultas Ekonomika dan Bisnis Universitas "X". Prosedur yang ada pada organisasi mahasiswa bertujuan untuk mengatur mekanisme aktivitas yang ada pada organisasi mahasiswa agar kinerjanya sesuai dengan tujuan organisasi.

Dengan prosedur yang telah ditetapkan masih ada beberapa pihak yang melakukan kinerja yang tidak sesuai dengan prosedur yang ada. Hal ini serupa dengan definisi dari fraud yang didefinisikan oleh ACFE bahwa kecurangan merupakan suatu tindakan yang disengaja dan pelaksanaanya tidak sesuai dengan peraturan - peraturan yang telah ditetapkan.

Dalam hal penggunaan aset yang dimiliki oleh organisasi ada beberapa anggota organisasi yang menggunakan aset organisasi untuk keperluan pribadi. Kecurangan yang dilakukan bisa berupa pemakaian fasilitas yang dimiliki oleh organisasi untuk keperluan pribadi bahkan ada yang menggambil kas milik organisasi untuk keperluan pribadi. 
Untuk lembaga legislatif dan eksekutif yang ada pada lembaga kemahasiswaan Fakultas Ekonomika dan Bisnis Universitas " $X$ " yang memiliki fasilitas kantor untuk mengerjakan kinerjanya, terdapat tindakan kecurangan yang berkaitan dengan penyalahgunaan aset organisasi seperti yang terpapar pada hasil wawancara berikut:

Menurut salah satu anggota Badan Perwakilan Mahasiswa Fakultas :

\section{"biasanya ada kak seperti memakai alat tulis punya kantor itu dipinjam atau gimana tapi waktu kembali sudah habis"}

Penyataan dari salah satu anggota Badan Perwakilan Mahasiswa Fakultas ini didukung oleh pernyataan salah satu anggota Senat Mahasiswa Fakultas yang menyatakan bahwa penyelewengan aset organisasi pasti terjadi dalam organisasi mahasiswa. Bahkan penyelewengan aset organisasi bisa berdampak bagi organisasi apabila aset yang diperlukan tidak ada pada saat dibutuhkan sehingga dapat menghambat acara yang diadakan oleh suatu organisasi.

Untuk lembaga yang berada pada naungan Senat Mahasiswa Fakultas dalam bidang olahraga mengaku jarang terjadi penyalahgunaan aset dalam kinerjanya. Hal ini dikarenakan aset yang dimiliki oleh lembaga olahraga hanya peralatan olahraga, kas yang digunakan untuk kegiatan, dan kantor yang digunakan secara bersama oleh seluruh bidang olahraga yang ada pada lembaga kemahasiswaan Fakultas Ekonomika dan Bisnis Universitas " $\mathrm{X}$ ". Disisi lain ada juga peraturan yang memperbolehkan anggota organisasi membawa pulang peralatan olahraga organisasi.

Sedangkan untuk lembaga naungan Senat Mahasiswa Fakultas yang berada pada bidang non olahraga dan profesional yang memiliki fasilitas kantor dan kas untuk kegiatan lembaga terdapat beberapa tindakan kecurangan yang dapat ditemukan. Hal ini dipaparkan dalam hasil wawancara berikut :

Menurut salah satu anggota Organisasi Jurnalistik :

"pasti ada kalau memakai alat alat fasilitas punya organisasi terus dipakai untuk pribadi kaya printer buat nge-print tugas atau alat alat tulis yang dipakai sendiri buat kepentingan pribadi"

Hal serupa juga dinyatakan oleh anggota dari Organisasi Perfilman, Himpunan Mahasiswa Progdi Akuntansi dan Himpunan Mahasiswa Progdi Manajemen bahwa penyalahgunaan aset yang biasa terjadi pada organisasi mahasiswa adalah peemakaian fasilitas yang dimiliki oleh organisasi untuk kepentingan pribadi dan menggunakan aset organisasi tidak sesuai dengan prosedur yang ada. Contoh dari penyalahgunaan aset pada organisasi mahasiswa adalah memakai alat-alat yang dimiliki oleh organisasi seperti alat tulis, printer, komputer yang digunakan untuk mengerjakan tugas atau memenuhi keinginan pribadi. Contoh lainnya adalah dalam peminjaman aset masih ada beberapa anggota yang meminjam tidak sesuai dengan prosedur yang ada sehingga menimbulkan kerugian bagi

Penyalahgunaan aset dalam organisasi mahasiswa masih dianggap sederhana karena tidak terlalu berdampak bagi organisasi dan dapat cepat untuk diselesaikan. Tetapi ada juga yang berdampak terhadap organisasi apabila penyelesaiannya cukup lama. Penyalahgunaan aset yang terjadi pada organisasi mahasiswa dinilai tidak begitu merugikan organisasi karena masih dianggap wajar bagi mahasiswa.

Kecurangan yang dapat terjadi dalam organisasi mahasiswa juga berkaitan dengan pembuatan laporan kegiatan, anggaran dan laporan pertanggungjawaban. Pada Lembaga Kemahasiswaan Fakultas Ekonomika dan 
Bisnis Universitas " $X$ ", setiap organisasi yang melakukan aktivitas diwajibkan untuk membuat proposal kegiatan dan anggaran terlebih dahulu, setelah aktivitas atau acara yang diadakan selesai setiap organisasi diwajibkan untuk membuat laporan pertanggungjawaban yang nantinya akan diserahkan kepada atasan dari organisasi yang bersangkutan. Dalam hal pembuatan laporan-laporan yang dibutuhkan, masih ada beberapa anggota yang melakukan kecurangan seperti hasil dari wawancara berikut ini:

Meurut salah satu anggota Senat Mahasiswa Fakultas :

"secara umum ada masalah anggaran dimana anggaran itu banyak di manipulasi bukan hanya saat penganggaran saja tapi saat laporan pertanggungjawaban juga teman teman juga masih berusaha untuk istilahnya mengenolkan anggaran mereka tetapi tidak memberitahukan ternyata masi ada sisa anggaran yang masi ada"

Hal yang serupa juga dinyatakan oleh beberapa organisasi lainnya seperti Organisasi Olahraga Bola Voly, Organisasi Jurnalistik, Organisasi Perfilman, Organisasi Pencinta Alam, dan Organisasi Kerohanian yang menyatakan bahwa kecurangan yang terjadi pada organisasi mahasiswa berkaitan dengan pembuatan laporan yang dibutuhkan oleh organisasi. Bentuk laporan yang ada pada organisasi mahasiwa berupa laporan kegiatan, anggaran dan pertanggungjawaban. Bahkan salah satu anggota Himpunan Mahasiswa Progdi Akuntansi menyatakan bahwa kecurangan yang terjadi pada laporan dikarenakan tekanan dari atasan seperti pada wawancara berikut ini :

"senyatanya ada beberapa yang masih mengabaikan ketentuanya misalnya dalam plot anggaran itu rawan sekali dalam temanteman di organisasi itu sulit sekali untuk menaati ketentuan ketentuannya karena disisi lain dari pihak yang membuat ketentuan sendiri mereka pinginnya temen-temen di suatu organisasi membuat suatu acara itu yang dituju itu kualitas acaranya. Sedangkan, sebagai yang melaksanakan acara teman-temen organisasi juga memikirkan bagaimana anggaran untuk mencapai kualitas tersebut jadi teman teman di organisasi masih ada yang mengutak atik anggaran tersebut"

Narasumber lain menyatakan bahwa tidak pernah mengetahui adanya kecurangan dalam pembuatan laporan kegiatan, anggaran maupun laporan pertanggungjawaban. Hal ini juga dikarenakan narasumber yang bersangkutan tidak pernah ikut serta dalam pembuatan laporan kegiatan, anggaran dan laporan pertanggungjawaban organisasinya.

Manipulasi laporan yang dilakukan oleh organisasi mahasiswa bukan manipulasi laporan keuangan seperti pada perusahaan biasanya. Manipulasi dilakukan pada proposal kegiatan, anggaran dan juga laporan pertanggungjawaban yang dihasilkan oleh organisasi yang bersangkutan. Dalam melakukan manipulasi anggaran dan laporan pertanggungjawaban ada kalanya organisasi mahasiswa memakai nota kosong untuk anggaran dan laporan pertanggungjawaban yang dihasilkan.

Bagi organisasi mahasiswa memanipulasi laporan sudah biasa terjadi, hal ini bukan tanpa alasan. Alasan mereka melakukan manipulasi laporan kegiatan, anggaran dan laporan pertanggungjawaban adalah menyisakan dana untuk panitia yang telah bekerja keras untuk acara organisasi tersebut, hal ini biasa dikenal dengan istilah pembubaran panitia. Semua narasumber mengatakan bahwa pembubaran panitia adalah hal yang wajar apabila dalam 
suatu acara ada kerja keras dari panitia yang bersangkutan dalam mencari usaha dana, tetapi pembubaran akan menjadi tidak wajar apabila dana yang diperoleh untuk acara yang diselenggarakan semua dari fakultas tanpa ada usaha dana dari panitia.

Kecurangan yang terjadi dalam organisasi mahasiswa mengandung tiga faktor yang ada dalam fraud triangle karena untuk melakukan kecurangan anggota organisasi mendapatkan tekanan dari atasan untuk kualitas acara yang sesuai dengan anggaran yang ada sehingga ada manipulasi anggaran dan juga laporan pertanggungjawaban. Pelaku kecurangan juga bisa mendapat tekanan dari dalam diri seperti tekanan akademik atau sosial untuk memakai fasilitas yang dimiliki oleh organisasinya.

Anggota organisasi juga memiliki peluang untuk melakukan kecurangan karena sebagian besar anggota yang melakukan kecurangan adalah anggota yang memiliki wewenang pada fasilitas yang dimiliki oleh organisasi. Dalam pembuatan laporan laporan organisasi, yang melakukan kecurangan juga anggota yang memiliki wewenang dalam pembuatannya. Untuk rasionalisasi terjadi pada saat anggota organisasi menganggap bahwa dana yang diperoleh dari hasil manipulasi laporan wajar apabila dana tersebut digunakan untuk pembubaran panitia karena dirasa panitia yang telah bekerja keras mencari usada dana demi acara organisasi mempunyai hak atas dana tersebut.

(Kummer et al., 2015) mendefinisikan penyalahgunaan aset sebagai tindakan kecurangan yang biasanya dilakukan oleh anggota organisasi dengan cara memanfaatkan aset organisasi untuk kepentingan pribadi dan manipulasi laporan keuangan pada organisasi juga termasuk dalam kecurangan karena pelaku kecurangan dapat mengubah hasil laporan bahkan memalsukan dokumen yang terkait dengan laporan dalam penelitiannya.
Tiffani dan Marfuah (2015) menjelaskan dalam penelitiannya bahwa kecurangan didasari oleh tekanan yang dirasakan oleh pelakunya dan peluang serta kondisi pelaku dapat mendukung pelaku untuk melakukan tindakan kecurangan. Kecurangan dapat dilakukan oleh pelaku apabila tindakan tersebut dianggap rasional dimana pelaku kecurangan membenarkan tindakannya. Potensi Whistleblowing pada Organisasi Mahasiswa untuk Pencegahan Kecurangan

Dari beberapa jenis kecurangan yang ada, ada beberapa anggota organisasi yang akan melaporkan kecurangan yang diketahuinya kepada atasan atau orang lain yang berkepentingan dengan organisasi yang bersangkutan apabila anggota tersebut mengetahui tindakan kecurangan tersebut seperti hasil wawancara berikut ini:

Menurut salah satu anggota Organisasi Teater :

"kalau memang ada yang
seperti itu kecurangan) pasti saya laporkan kalau sesama anggota pasti saya laporkan pada ketua saya nanti kebijakannya biar ketua yang memutuskan bagaimana"

Pernyataan salah satu anggota Organisasi Teater ini selaras dengan pernyataan Badan Perwakilan Mahasiswa Fakultas, Senat Mahasiswa Fakultas, Organisasi Olahraga Bola Basket, Organisasi Olahraga Sepak Bola, Organisasi Olahraga Badminton, Organisasi Jurnalistik, Organisasi Perfilman, Organisasi Kerohanian dan Himpunan Mahasiswa Progdi Akuntansi yang akan melaporkan tindakan kecurangan yang terjadi di sekitar organisasi. Tujuan dari pelaporan kecurangan ini adalah sebagai evaluasi dan perbaikan aktivitas organisasi selanjutnya.

Tidak semua anggota organisasi akan langsung melaporkan tindakan 
kecurangan yang diketahuinya, ada beberapa anggota yang ingin menelusuri terlebih dahulu alasan pelaku kecurangan dalam melakukan tindak kecurangan baru setelahnya anggota organisasi yang bersangkutan akan menggambil tindakan atau melihat juga kondisi pada saat pelaku kecurangan melakukan kecurangan seperti berikut ini:

Menurut salah satu anggota Himpunan Mahasiswa Progdi Ilmu Pembangunan:

"kalau ada masalah yang kecil menurut saya tidak perlu dibuat besar karena kita kan sudah besar tau yang baik dan buruk jadi tidak perlu dilaporkan...tetapi kalau itu berdampak pada organisasi nanti pasti kita konsultasi dulu sama atasan nanti berunding bersama dan ambil keputusan bersama"

Hal yang sama juga dinyatakan oleh salah satu anggota Organisasi Olahraga Bola Voly dan Himpunan Mahasiswa Progdi Manajemen yang menyatakan akan melihat terlebih dahulu peristiwa kecurangan yang terjadi pada organisasi mahasiswa. Apabila kecurangan yang terjadi tidak begitu berpengaruh pada organisasi maka akan diselesaikan secara kekeluargaan, tetapi apabila tindakan kecurangan yang dapat merugikan organisasi baru akan dilaporkan untuk ditindaklanjuti.

Tidak semua anggota organisasi akan melaporkan tindakan kecurangan yang diketahuinya. Ada salah satu narasumber yang mengatakan tidak akan melaporkan tindakan kecurangan yang diketahuinya karena tidak berdampak langsung pada anggota tersebut, anggota tersebut akan melaporkannya apabila kecurangan yang terjadi berdampak langsung pada dirinya dan organisasi yang diikutinya seperti hasil wawancara berikut ini :
Menurut salah satu anggota Organisasi Pencinta Alam :

"teman saya pernah seperti itu (melakukan kecurangan) tapi saya diam saja karena itu tidak berpengaruh sama saya... kecuali kalau itu berpengaruh sama saya ya saya laporin bukan sama saya saja kalau itu berpengaruh sama organisasi saya ya juga saya laporin"

Tindakan pelaporan kecurangan yang dapat terjadi pada organisasi mahasiswa dianggap dapat dijadikan sesuatu hal yang dapat mencegah kecurangan yang mungkin terjadi dikemudian hari, apabila sudah terjadi aktivitas pelaporan kecurangan maka anggota yang lain akan merasa takut untuk melakukan tindak kecurangan karena merasa diawasi oleh anggota lainnya seperti yang terpapar pada hasil wawancara berikut ini :

Menurut salah satu anggota Organisasi Olahraga Bola Voly :

"kalau menurut aku ya kak, pasti bakal mencegah tindakan kecurangan, walaupun tidak seratus persen mungkin setidaknya akan mencegah hal tersebut terjadi. Karena apabila tindakan kecurangan yang satu dilaporkan maka otomatis yang akan berbuat selanjutnya berfikir dua kali, misalnya ketahuan pasti akan dilaporkan sehingga tindakan - tindakan yang sekiranya itu dinilai kecurangan akan berkurang"

Semua narasumber setuju dengan pernyataan bahwa aksi whistleblowing dapat mencegah aksi kecurangan pada masa yang akan datang. Setiap narasumber menyatakan bahwa aksi pelaporan ini bisa dijadikan untuk perbaikan bagi organisasi dan dapat meminimalisir tindakan kecurangan yang akan terjadi, hal ini dikarenakan aksi pelaporan ini dapat membuat orang yang 
akan melakukan kecurangan berpikir dua kali untuk melakukan kecurangan.

Hal ini sesuai dengan penelitian yang dilakukan oleh beberapa peneliti sebelumnya seperti Setiawati dan Sari (2016) yang menyatakan bahwa whistleblowing dapat meminimalkan tindakan kecurangan karena secara tidak langsung anggota organisasi yang tergabung di dalam organisasi saling mengawasi satu sama lain.

Organisasi mahasiswa memiliki potensi untuk dilakukan aksi whistleblowing, karena menurut beberapa anggota organisasi kecurangan harus diungkapkan untuk kebaikan organisasi. Dengan adanya aksi whistleblowing juga dapat mencegah tindakan kecurangan untuk kedepannya karena anggota organisasi pasti merasa diawasi dalam aktivitas organisasinya. Dalam penelitiaanya (Gaurina et al., 2017) juga memaparkan bahwa penerapan pencegahan kecurangan dapat membantu organisasi untuk mengidentifikasi kecurangan yang dapat terjadi pada suatu organisasi.

\section{Model Whistlebowing Pada Organisasi Mahasiswa}

Pada organisasi mahasiswa sebagian besar narasumber mengatakan bahwa lebih baik menggunakan model anonymous yang merahasiakan identitas pelapor kecurangan. Bukan tanpa alasan narasumber memilih model anonymous, hal ini dikarenakan ketakutan apabila terjadi hal hal yang tidak diinginkan seperti pemusuhan dalam organisasi mahasiswa seperti hasil wawancara berikut ini :

Menurut salah satu anggota Organisasi Olahraga Sepak Bola :

"di keep aja identitasnya biar tidak jadi masalah antar anggota"

Sama halnya dengan anggota Badan Perwakilan Mahasiswa Fakultas,
Senat Mahasiswa Fakultas, Organisasi Olahraga Badminton, Organisasi Olahraga Sepak Bola, Organisasi Pencinta Alam, Organisasi Teater, Organisasi Kerohanian, Organisasi Jurnalistik dan Himpunan Mahasiswa Progdi Akuntansi yang setuju dengan model anonymous. Model anonymous digunakan untuk mengurangi risiko terjadinya konflik antara pelaku dan pelapor kecurangan.

Ada seorang narasumber yang beranggapan bahwa identitas pelapor sebaiknya tidak diungkapkan terlebih dahulu tetapi apabila ada keperluan untuk memperdalam bukti baru identitas pelapor dapat diungkapkan seperti hasil wawancara berikut ini:

Menurut salah satu anggota Himpunan Mahasiswa Progdi Manajemen :

“...enaknya di-keep dulu identitasnya tetapi kalau dia (pelaku kecurangan) melawan baru kita ungkapkan identitasnya untuk bukti"

Tidak semua narasumber beranggapan untuk menggunakan model anonymous, ada beberapa narasumber yang mengatakan bahwa model nonanonymous lebih baik karena identitas dari pelapor kecurangan diungkapkan agar masalah yang terjadi dapat terselesaikan seperti yang terpapar pada hasil wawancara berikut ini :

Menurut salah satu anggota Organisasi Olahraga Bola Basket :

"lebih baik diungkapkan siapa yang melaporkan karena misalnya kita yang dilaporkan terus tidak tahu siapa yang melaporkan kan jadi tanya sana sini siapa yang melaporkan kan lebih enak diungkapkan terus dirundingkan bersama"

Selaras dengan pernyataan salah satu anggota Organisasi Olahraga Bola Basket, anggota Organisasi Olahraga 
Bola Voly, Organisasi Perfilman dan Himpunan Mahasiswa Progdi Ilmu Pembangunan juga menyatakan lebih baik menggunakan model nonanonymous. Model non-anonymous digunakan agar penyelesaian masalah dapat dirundingkan secara terbuka dan diselesaikan bersama sama dengan anggota lainnya.

Pelaporan kecurangan dapat dilakukan dengan dua model yaitu model anonymous dan non-anonymous, penelitian yang dilakukan oleh Gokce (2013) mengatakan bahwa model anonymous tidak mengungkapkan identitas pelapor pada publik dan pelapor dapat menggunakan nama singkatan atau bahkan tidak menggungkapkan identitas sama sekali dalam melaporkan tindakan kecurangan. Berbeda dengan anonymous,non-anonymous mengungkapkan identitas dari pelapor kecurangan.

Model whistleblowing yang dapat diterapkan pada organisasi mahasiwa dapat dilihat dari kondisi kecurangan yang terjadi. Model anonymous dapat diterapkan untuk mengurangi resiko permusuhan dalam organisasi, tetapi apabila dibutuhkan untuk penguatan bukti kecurangan model non-anonymous dapat diberlakukan.

\section{Simpulan Dan Saran}

Hasil penelitian menunjukkan bahwa jenis kecurangan yang dapat terjadi pada organisasi mahasiswa adalah terkait dengan penyalahgunaan aset dan manipulasi laporan keuangan. Penyalahgunaan aset yang terjadi pada organisasi mahasiswa dapat berupa menggunakan aset - aset yang diperuntukkan untuk kepentingan organisasi sebagai kepentingan pribadi, seperti memakai fasilitas, kas, peralatan organisasi untuk kepentingan pribadi. Manipulasi laporan yang terjadi pada organisasi mahasiswa terjadi pada laporan anggaran dan pertanggungjawaban yang digunakan pada acara yang diadakan oleh organisasi seperti memanipulasi saldo-saldo yang ada pada laporan dengan menggunakan nota kosong sebagai bukti transaksi.

Dilihat dari hasil identifikasi tindakan kecurangan yang dapat terjadi pada organisasi mahasiswa terdapat potensi whistleblowing yang dapat dilakukan oleh anggota organisasi yang dapat memberikan manfaat sebagai pencegahan tindakan kecurangan. Model whistleblowing yang dapat diterapkan pada organisasi mahasiswa adalah model anonymous yang dalam pelaksanaannya tidak mempublikasikan identitas pelapor agar tidak terjadi permusuhan dalam organisasi.

\section{Implikasi}

Hasil dari penelitian ini dapat digunakan oleh organisasi mahasiswa untuk mengetahui kekurangan dari operasional kegiatan kemahasiswaan yang selama ini dilakukan dan dapat mengidentifikasi lebih lanjut mengenai tindakan - tindakan kecurangan yang dapat terjadi pada organisasinya, sekaligus sebagai bahan evaluasi agar tindakan kecurangan dapat diminimalisir. Hasil dari penelitan ini juga dapat digunakan sebagai dasar pembuatan sistem whistleblowing untuk organisasi mahasiswa karena dapat diketahui bahwa terdapat potensi whistleblowing pada organisasi mahasiswa dengan menggunakan model anonymous.

\section{Keterbatasan dan Saran}

Penelitian ini terbatas pada beberapa calon narasumber yang menolak untuk melakukan wawancara dan menolak untuk menjawab pertanyaan wawancara karena tidak begitu paham dengan mekanisme kerja organisasi. Topik penelitian yang sensitif menyebabkan informasi yang diperoleh dari narasumber tidak merefleksikan hasil wawancara dengan keadaan yang sebenarnya. Observasi tidak dapat 
dilakukan dengan maksimal, dikarenakan narasumber tidak melakukan pekerjaannya di kantor universitas. Penelitian mendatang diharapkan menambah variasi narasumber dari berbagai unsur lembaga atau organisasi kemahasiswaan dan dari beragam fakultas dalam sebuah universitas.

\section{Daftar Pustaka}

ACFE. (2017). What Is Fraud? Retrieved June 6, 2017, from http://www.acfe.com/fraud101.aspx

ACFE. (2017a). The Fraud Triangle. Retrieved June 6, 2017, from http://www.acfe.com/fraudtriangle.aspx

Agusyani, K. S., Sujana, E., \& Wahyuni, M. A. (2016). Pengaruh whistleblowing system dan kompetensi fraud pada pengelolaan keuangan penerimaan pendapatan asli daerah ( studi pada dinas pendapatan daerah kabupaten buleleng ). Univ Pendidikan Ganesha, 1, 1-10.

Arfah, E. A. (2011). Pencegahan fraud pengadaan barang dan implikasinya pada kinerja keuangan ( studi pada rumah sakit pemerintah dan swasta di kota Bandung ). Jurnal Investasi, 7(2), 137-153.

Christian, A. (2015). Sosok "whistle blower" dalam membongkar korupsi FIFA. Retrieved November 12, 2017, from http://bola.kompas.com/read/2015/0 5/27/17025468/Sosok. Whistle.Blow er.dalam.Membongkar.Korupsi.FIF A

Gaurina, N. P. M., Purnamawati, I. G. A., \& Atmadja, A. T. (2017). Pengaruh persepsi karyawan mengenai perilaku etis dan whistleblowing system terhadap pencegahan fraud (studi kasus pada Bali Hai Cruises). Jurnal Ilmiah Mahasiswa Akuntansi Universitas Pendidikan Ganesha, 8(2). Retrieved from https://ejournal.undiksha.ac.id/inde x.php/S1ak/article/view/10450

Gokce, A. T. (2013). Teachers' value orientations as determinants of preference for external and anonymous whistleblowing. International Journal of Humanities and Social Science, 163-173. Retrieved from https://www.researchgate.net/public ation/261296887_Teachers\%27_Va lue_Orientations_as_Determinants_ of_Preference_for_External_and_A nonymous_Whistleblowing

Kummer, T.-F., Singh, K., \& Best, P. (2015). The effectiveness of fraud detection instruments in not-forprofit organizations. Managerial Auditing Journal, 30(4/5), 435-455. https://doi.org/10.1108/MAJ-082014-1083

Mada, K. R. (2012). Penimbunan solar rugikan negara $\mathrm{Rp}$ 21,5 Miliar. Retrieved November 12, 2017, from http://regional.kompas.com/read/20 12/10/05/11401833/Penimbunan.So lar.Rugikan.Negara.Rp.21.5.Miliar

Puspita, Y. R., Haryadi, B., \& Setiawan, A. R. (2015). Sisi remang pengelolaan keuangan organisasi mahasiswa. Jurnal Akuntansi Multiparadigma. https://doi.org/10.18202/jamal.2015 .04 .6011

Sagara, Y. (2013). Profesionalisme internal auditor dan intensi melakukanwhistleblowing. Jurnal Liquidity, 2(1), 34-44.

Setiawati, L. P., \& Sari, M. M. R. (2016). Profesionalisme, komitmen organisasi, intensitas moral dan tindakan akuntan melakukan whistleblowing. E-Journal Akuntansi Universitas Udayana, 
17(1), 257-282. Retrieved from https://ojs.unud.ac.id/index.php/Ak untansi/article/view/18947

Tiffani, L., \& Marfuah. (2015). Deteksi financial statement fraud dengan analisis fraud triangle pada perusahaan manufaktur yang terdaftar di bursa efek Indonesia. Jurnal Akuntansi Dan Auditing Indonesia, 19(2), 112-125. Retrieved from http://journal.uii.ac.id/index.php/JA AI/article/view/4330

UKSW. (2011). Ketentuan Umum Keluarga Mahasiswa Universitas Kristen Satya Wacana.

Yeoh, P. (2014). Whistleblowing: motivations, corporate selfregulation, and the law. International Journal of Law and Management, 56(6), 459-474. https://doi.org/10.1108/IJLMA-062013-0027 